\title{
Soil Conservation and Water-Resources Management Techniques used by Small- Scale Rice Farmers in Ebonyi State, Nigeria https://dx.doi.org/10.4314/jae.v23i4.7
}

\section{Obinna, Leo. 0.}

Department of Rural Sociology and Extension

College of Agricultural Economics, Rural Sociology and Extension

Michael Okpara University of Agriculture, Umudike

E-mail Obinna.leo@mouau.edu.ng or Obinna.leo@2gmail.com.

Phone: 08035454465

\section{Abstract}

The study assessed s soil conservation and water - resources management techniques among small- scale rice farmers in Ebonyi State. A sample of 130 respondents generated via multi- stage, purposive and simple random methods were used. Data were generated through questionnaire and interview schedule and analysed using percentage and mean. Results, showed the indigenous methods for soil and water- resources management used by the rice farmers to include: construction of basin and flow walls ( $\bar{x}=$ $92.3 \%)$, construction of dikes ( $\bar{x}=84.6 \%)$, ration- harvesting $(\bar{x}=73 \%)$, and compost- manuring ( $\bar{x}=69 \%$ ). Other indigenous methods used include: use of IPM ( $\bar{x}=65.4 \%)$, shifting cultivation and planting of trees ( $\bar{x}=61.5 \%)$, crop rotation $(\bar{x}=57.7 \%)$ and Mixed cropping ( $\bar{x}=50.0 \%)$. Results on level of use of the Agronomical Best Environmental Management Practices (ABEMPs) through physical measures indicated that construction of bund- lines $(\bar{x}=$ 3.23) and farm-drainage $(\bar{x}=3.00)$ were at high level of use, while levelling $(\bar{x}=2.96)$, dikes $(\bar{x}=2.77)$, stone- lines $(\bar{x}=2.39)$, terracing $(\bar{x}=2.15)$ were at moderate level of use and plastic mulching $(\bar{x}=1.85)$ was at low level of use. Equally, for biological measures mixed-cropping $(\bar{x}=3.08)$ was at high level of use, while crop- rotation ( $\bar{x}=2.80$ ), planting of trees $(\bar{x}=2.62)$ and fallowcover $(\bar{x}=2.23)$ were at moderate level of use and incorporation of residues $(\bar{x}=1.92)$ was at low level of use. On the Best Agronomic Practice measures, results showed conservation tillage and liming $(\bar{x}=3.00)$ were respectively at high level of use, while mount- making / ridging ( $\bar{x}=2.92)$, application of compost manure ( $\bar{x}=2.62)$, use of IPM (2.62) and application of cow dung and poultry droppings $(\bar{x}=2.50)$ were at moderate level of use, while irrigation $(\bar{x}=1.77)$ and zero tillage $(\bar{x}=1.23)$ were at low level of use respectively. The indigenous and ABEMPs methods are geared towards stable renewable resource use through sustainable (soil and water- resources) management techniques. There should be enhanced farmer-scientist research collaboration to develop soil and water- resource management techniques for more sustainable for rice production in the study area. 
Creative Commons User License: CC BY-NC-ND

Abstracted by: EBSCOhost, Electronic Journals Service (EJS),

Google Scholar, Journal Seek, Scientific Commons,

Food and Agricultural Organization (FAO), CABI and Scopus
Journal of Agricultural Extension

Vol. 23 (4) October, 2019

ISSN(e): 24086851; ISSN(Print); 1119944X

http://journal.aesonnigeria.org

http://www.ajol.info/index.php/jae

Email: editorinchief@aesonnigeria.org

\section{Key Words: Indigenous ABEMPs, soil and water- resources, rice farmers.}

\section{Introduction}

The need to improve environmental performance for agriculture, through enhancing environmental friendly practices to ensure the sustainability of resource use, has been severally emphasized. Agriculture is an important sector of the Nigerian economy. It is a major user of land and water resources yet needs to maintain the quantity and quality of those resources in order to remain viable (National Agricultural Extension and Research Liaison Services (NAERLS) 2017). It generates waste and pollution and yet recycles natural resources, and changes landscapes and habitats for wildlife (NAERLS, 2017). For agriculture to continue to be viable within the conservation needs of the farm, surrounding area, and water- shed, farming operations have to be sustainably managed as to help preserve and restore critical habitats, protect water- sheds and improve soil health and water quality (NAERLS, 2017).

The Agricultural Best Environmental Management Practices (ABEMP) are techniques, measures or actions that allow farmers to minimize their impact on the environment in all aspects under their direct control or on which they have a considerable influence (NAERLS, 2017). It is site specific, economically feasible and is based on the best available research and scientific data from a given place. It depends on other local factors such as topography, soil texture, water regime and farming system. Based on the above that NAERLS (2017) divided measures for soil conservation and water resources management techniques into three namely: physical measures (mechanical/ technical measures), biological measures (vegetative), and agronomic measures or best management practices. The best management practices (BMPs) are sustainability centred and should be implemented systematically, through selection, design and implementation. According to Odoemelam (2015) sustainability implies utilizing these resources (soil and water) in ways that ensure little or no damage whilst guaranteeing their continuous usage.

Production ecologies for rice in Nigeria include: rain-fed lowland, rain-fed up - land, irrigated rice, deep- water/ floating rice and mangrove (NAERLS, 2017). The land area potential for rice production in Nigeria is between 4.6million and 4.9million hectares. Out of this, only about 1.7 million hectares or 35 percent of the available land area is presently cropped to rice (Provide the source). The main production ecologies for rice in Nigeria are rain-fed lowland, which has the largest share of the rice area (50\%) and rice production (West Africa Rice Development Association (WARDA) (2003). Small-scale farmers with farm holdings of less than one hectare, plant most of the rice produced in Nigeria. However, rice productivity and production at the farm level are constrained by several factors, such as; ineffective farmer organizations and groups, low yield and poor milling quality of local rice varieties, poor marketing arrangements, inconsistent agricultural input and rice trade policies, 
Creative Commons User License: CC BY-NC-ND

Abstracted by: EBSCOhost, Electronic Journals Service (EJS), Google Scholar, Journal Seek, Scientific Commons,

Food and Agricultural Organization (FAO), CABI and Scopus
Journal of Agricultural Extension

Vol. 23 (4) October, 2019

ISSN(e): 24086851; ISSN(Print); 1119944X

http://journal.aesonnigeria.org

http://www.ajol.info/index.php/iae

Email: editorinchief@aesonnigeria.org

poor extension systems and environmental constraints (NAERLS, 2017). These environmental constraints include poor drainage and iron toxicity in undeveloped lowland management practices (West Africa Rice Development Association (WARDA) 2003). About $80 \%$ of rice producers in Ebonyi State are small- scale farmers who employ subsistent methods in their farm operations (Ebonyi State ADP, (EBADP), 2016). Their farming operations depend heavily on the timing and length of the rainy season (EBADP, 2016)). Most rice farmers in Ebonyi State cultivate the local varieties of rice such IR8, IR5, ITA 306, MASS, EX- China (90 days) (mostly in Izi-Ugumego and Ndiechionuabonyi Communities) and Ikwo within the shallow swamps (Fadama) of Cross River banks (Longtau, 2013). The rice farmers equally practice mono- cropping in Ikwo area and mixed- cropping in Abakaliki area, either through direct seeded (broadcast) or transplanted from nursery which are rain-fed. It is only in Ezi - llo community farm that irrigated rice through gravity is cultivated (EBADP, 2016). The land preparation is oftentimes done through manual labour which involves bonding and levelling (flat land or basins) inorder to impound water to permit even flooding (EBADP, 2016). To the best knowledge of the researcher, no empirical study has been carried out on the assessment of soil conservation and water- resources management techniques among small- scale rice farmers in Ebonyi State. It was based on the aforementioned that the following research objectives guided the study, which included to:

(i) identify the indigenous methods of conserving soil and water - resources in the rice farms by the respondents; and

(ii) determine the level of use of physical measures in line with the best environmental management practices (BEMPs) by the respondents in conserving soil and water- resources in the rice farms.

\section{Methodology}

The study was conducted in Ebonyi State, which is one of the 36 states of Nigeria including the FCT Abuja. The state is located between Latitudes $5^{\circ} 4^{\prime \prime}$ and $6^{\circ} 45^{\prime \prime}$ North of Equator and Longitudes $7^{0} 30^{\prime \prime}$ and $8^{\circ} 40^{\prime \prime}$ East of Greenwich Meridian (Obinna and Nzeakor, 2017). The state is also situated in the South - east agro ecological zone of Nigeria, occupying a land area of about $5,935 \mathrm{~km}^{2}$ and population of about 2.3 million persons (NPC, 2007). Ebonyi state is divided into three Agricultural Zones namely: Ebonyi North, Central and Ebonyi South Agricultural Zones respectively (EBADP,2016). The major occupation in Ebonyi State is predominantly rice farming (EBADP, 2016). Ebonyi State is blessed with good soil and environment suitable for agriculture with average annual rainfall of $1200 \mathrm{~mm}-$ $2000 \mathrm{~mm}$ and temperature range of $33^{\circ} \mathrm{C}$ during the dry season and $18^{\circ} \mathrm{C}$ during the rainy season (EBADP, 2016). The dominating method of cultivating rice in Ebonyi is rain fed cultivation (Fadama) in small-scale levels. Irrigation is minimally available (gravity irrigation) (EBADP,2016).

Multi- stage, purposive and randomized sampling procedures were used in selecting a sample size of 130 respondents that were used for the study. In stage 1; From the records of EBADP, two agricultural zones of the state where rice is predominantly 
Creative Commons User License: CC BY-NC-ND

Abstracted by: EBSCOhost, Electronic Journals Service (EJS), Google Scholar, Journal Seek, Scientific Commons,

Food and Agricultural Organization (FAO), CABI and Scopus
Journal of Agricultural Extension

Vol. 23 (4) October, 2019

ISSN(e): 24086851; ISSN(Print); 1119944X

http://journal.aesonnigeria.org

http://www.ajol.info/index.php/jae

Email: editorinchief@aesonnigeria.org

cultivated, were purposively selected. In stage 2; one agricultural block (AB) was randomly selected from each of the two selected AZs. In stage 3; five agricultural Cells (ACs) were randomly selected from each of the two ABs to give a total of 10 cells. In stage 4; with the assistance of the extension agent in charge of the cells 13 rice farmers were randomly selected from each of the 10 cells to give a total of 130 rice farmers that were used for the study. Primary data were generated through the use of questionnaire and interview schedule. Data were analysed through the use of frequency count, percentage, mean, pooled mean responses, and cumulative frequency and ranks respectively. weighted and scored 1 point respectively. A bench mark of 2.5 was chosen for decision rule that any mean responses $\geq 2.5$ was regarded significant, while any mean responses $<2.5$ was regarded not significant. Level of utilization was determined thus:

$$
\begin{aligned}
& 0.0-0.99=\text { very low level of utilization } \\
& 1.0-1.99=\text { low level of utilization } \\
& 2.0-2.99=\text { moderate level of utilization } \\
& 3.0-4.00=\text { high level of utilization }
\end{aligned}
$$

\section{Results and Discussion}

Table 1 shows that $92.3 \%$ of the farmers employed construction of basin as one of the indigenous methods of managing soil and water-resources in the rice fields and it ranked $1^{\text {st }}$. The Table equally shows that $84.6 \%$ of the farmers used construction of farm- drainage and construction of bunds/ dikes as one of the ways of managing soil and water- resources and they ranked $2^{\text {nd }}$ respectively. About $73.1 \%$ of the farmers used ration- harvesting for soil and water- resources management and it ranked $4^{\text {th }}$. Also, about $69.2 \%$ of the farmers used compost- manure and incorporation of rice- bran residues for soil and water- resources management respectively and they ranked $5^{\text {th }}$ (Table 2$)$. The Table further shows that $65.3 \%$ of the farmers used Integrated Pest Management (IPM) methods for soil and waterresources management and it ranked $7^{\text {th }}$ and also, $61.5 \%$ of farmers employed shifting cultivation and planting of trees respectively for soil and water- resources management and they ranked $8^{\text {th }}$ respectively. Table 2 further shows that $57 \%$ of the farmers used crop- rotation and it ranked $10^{\text {th }}$ and equally, about $50 \%$ of the farmers used mixed- cropping and it ranked $11^{\text {th }}$. Table 2 equally, shows that about $46.2 \%$, $30.8 \%$ and $23 \%$ respectively of the farmers used cover- cropping, minimum tillage and ridging respectively for soil and water- resources management and they ranked $12^{\text {th }}, 13^{\text {th }}$ and $14^{\text {th }}$ respectively. The result implies that the indigenous methods of managing soil and water- resources by the rice farmers in the study area include: Basin construction, farm- drainage, bunds/ dikes construction, ration- harvesting, compost- manuring, incorporation of rice bran/ mulching, use of IPM, shifting cultivation, planting of trees, crop- rotation and mixed farming respectively. This corroborates NAERLS (2017) which, argued that for agriculture to remain sustainable, that the Agricultural Best Environmental Management Practices (ABEMP) must be adopted in every farming operation and must be location specific. 
Creative Commons User License: CC BY-NC-ND

Abstracted by: EBSCOhost, Electronic Journals Service (EJS), Google Scholar, Journal Seek, Scientific Commons,

Food and Agricultural Organization (FAO), CABI and Scopus
Journal of Agricultural Extension

Vol. 23 (4) October, 2019

ISSN(e): 24086851; ISSN(Print); 1119944X

http://journal.aesonnigeria.org

http://www.ajol.info/index.php/iae

Email: editorinchief@aesonnigeria.org

Table 1: Indigenous use of soil and water- resources management methods.

\begin{tabular}{lcc}
$\begin{array}{l}\text { Soil \& Water- Resources Management } \\
\text { Techniques }\end{array}$ & Percentages (\%) & Ranks \\
Construction of Basins & 92.31 & $1^{\text {st }}$ \\
Construction of farm drainage & 84.61 & $2^{\text {nd }}$ \\
Construction of bunds/ dikes & 84.61 & $2^{\text {nd }}$ \\
Ration- harvesting & 73.08 & $4^{\text {th }}$ \\
Compost- manuring & 69.23 & $5^{\text {th }}$ \\
Incorporation of rice bran \& mulching & 69.23 & $5^{\text {th }}$ \\
Use of IPM systems & 65.30 & $7^{\text {th }}$ \\
Shifting Cultivation & 61.54 & $8^{\text {th }}$ \\
Planting of trees & 61.54 & $8^{\text {th }}$ \\
Crop- rotation & 57.69 & $10^{\text {th }}$ \\
Mixed - cropping & 50.00 & $11^{\text {th }}$ \\
Cover- cropping & 46.15 & $12^{\text {th }}$ \\
Minimum Tillage & 30.77 & $13^{\text {th }}$ \\
Ridging & 23.07 & $\cdot 14^{\text {th }}$ \\
\hline
\end{tabular}

N/B any responses $\geq 50 \%$ was regarded as significant. Source: Field Survey 2018.

\section{Best Environmental Management Practices in Soil and Water- Resources Management Techniques among Rice Farmers.}

In the use of physical measures (A) Table 2 shows that the rice farmers made use of construction of bund- lines ( $\bar{x}=3.23)$ and construction of farm- drainage $(\bar{x}=3.00)$ as measures for soil and water- resources management technique at a high level of utilization. This implies that the respondents in the study area still make use of indigenous techniques in the management of soil and water resources. The Table equally shows that the respondents, made use of levelling ( $\bar{x}=2.96)$, construction of dikes ( $\bar{x}=2.77)$, construction of stone- lines $(\bar{x}=2.39)$, terracing $(\bar{x}=2.15)$, contourfarming $(\bar{x}=2.11)$ and sand bag- line walls $(\bar{x}=2.00)$ at a moderate level of utilization in their rice farms. This implies that the respondents made use of any technique that is affordable and common among them in the management of soil and water resources management.

Table 2 further shows that farmers utilized plastic mulching $(\bar{x}=1.85)$ at low level of utilization. This implies that the type of physical measures employed by the rice farmers depended on their indigenous knowledge since they are small- scale farmers who could not afford the high technologies. This is in agreement with NAERLS (2017) which postulated that soil conservation should be site specific, depending on the local factors such as topography, soil texture, water regime and farming system. In the use of vegetative Table shows that the farmers utilized mixed-cropping $(\bar{x}=3.08)$ at a high level of use in the soil and water- resources management technique, while they utilized crop- rotation ( $\bar{x}=2.85)$, planting of trees $(\bar{x}=2.62)$ and fallow cover $(\bar{x}=2.23)$ at moderate level of use. Table 2 further shows that incorporation of plant residues $(\bar{x}=1.92)$ was at low level of use by the respondents in the soil and water- resources management techniques. This implies that the incorporation of farm residues is not yet highly practiced among the farmers. The Table equally shows in the use of best agronomic measures, that conservation 
Creative Commons User License: CC BY-NC-ND

Abstracted by: EBSCOhost, Electronic Journals Service (EJS),

Google Scholar, Journal Seek, Scientific Commons,

Food and Agricultural Organization (FAO), CABI and Scopus
Journal of Agricultural Extension

Vol. 23 (4) October, 2019

ISSN(e): 24086851; ISSN(Print); 1119944X

http://journal.aesonnigeria.org

http://www.ajol.info/index.php/iae

Email: editorinchief@aesonnigeria.org

tillage $(\bar{x}=3.00)$ and liming $(\bar{x}=3.00)$ were utilized at high level of use by the respondents, mounds making/ ridging ( $\bar{x}=2.92)$, application of compost manure ( $\bar{x}=$ 2.62) and application of cow dung, pig dung and poultry droppings ( $\bar{x}=2.50)$ were employed at moderate level of use by the respondents in soil and water- resources management techniques. This implies that these techniques have been used in the soil and water resources management over time. Table 2 further shows that tractorization $(\bar{x}=1.77)$ and zero- tillage $(\bar{x}=1.230$ at low level of use by the respondents in soil and water - resources management techniques. The implication of the result is that there is no one- size fit all procedures in the application of $A B E M P$ in the soil and water - resources management techniques but rather proven methodologies that have been got through research to be appropriate for any given soil and farming system. The NAERLS (2017) reported that ABEMP is a technique, measures or actions that allow farmers to minimize their impact on the environment in all aspects under their direct control or on which they have a considerable influence. They equally, postulated that soil conservation should be site specific, depending on the local factors such as topography, soil texture, water regime and farming system.

Table 2: Level of use of ABEMP in their rice farms.

\begin{tabular}{lc}
\hline Soil and Water- Resources Management Techniques & Mean \\
\hline Physical Measures & \\
Construction of bund- lines & $3.23^{* * *}$ \\
Construction of farm- drainage & $3.00^{* * *}$ \\
Levelling & $2.96^{* *}$ \\
Construction of dikes & $2.77^{* *}$ \\
Construction of sand- line walls & $2.39^{* *}$ \\
Terracing & $2.15^{* *}$ \\
Contour- farming & $2.11^{* *}$ \\
Sand- bag walls & $2.00^{* *}$ \\
Plastic mulching & $1.85^{*}$ \\
Biological/ Vegetative Measures & \\
Mixed- cropping & $3.08^{* * *}$ \\
Crop- rotation & $2.85^{* *}$ \\
Planting of trees & $2.62^{* *}$ \\
Fallow- cover & $2.23^{* *}$ \\
Incorporation of residues & $1.92^{*}$ \\
Best Agronomic Measures & \\
Conservation tillage & $3.00^{* * *}$ \\
Liming & $3.00^{* * *}$ \\
Mounds/ Ridging & $2.92^{* *}$ \\
Compost manuring & $2.62^{* *}$ \\
Use of IPMs & $2.62^{* *}$ \\
Application of cow dung, pig dung \& poultry droppings & $2.5^{* *}$ \\
Tractorization & $1.92^{*}$ \\
Irrigation & $1.77^{*}$ \\
Zero tillage & $1.23^{*}$ \\
\hline
\end{tabular}

Source: Field Survey 2018

${ }^{* * *}$ (High Level of Use), ${ }^{* *}$ (Moderate Level of Use) and * (Low Level of Use)

\section{Conclusion and Recommendations}

The indigenous and ABEMPs methods are geared towards stable renewable resource use through sustainable (soil and water- resources) management 
Creative Commons User License: CC BY-NC-ND

Abstracted by: EBSCOhost, Electronic Journals Service (EJS), Google Scholar, Journal Seek, Scientific Commons,

Food and Agricultural Organization (FAO), CABI and Scopus
Journal of Agricultural Extension

Vol. 23 (4) October, 2019

ISSN(e): 24086851; ISSN(Print); 1119944X

http://journal.aesonnigeria.org

http://www.ajol.info/index.php/iae

Email: editorinchief@aesonnigeria.org

techniques which will ensure preservation of biodiversity, stable quality and quantity of fresh water, avoiding soil degradation through erosion, human activities and effect of climate change in order to assure sustainability of environment. There should be enhanced farmer - scientist research collaboration mostly in the study area in order to develop soil and water- resource management techniques that will be more sustainable for rice production in the study area.

\section{References}

Ebonyi State Agricultural Development Programme (EBADP) (2016): Annual Report 50.

Jara- Rojas, R., Bravo- Ureta Be and Dias, T (2012). Adoption of water conservation practices" A socioeconomic analysis of small- scale farmers in Central Chile, Agric. System 110; $54-62$.

Longtau, S. (2013). Multi- Agency Partnership I West African Agriculture: A Review and Description of Rice Production Systems in Nigeria. Overseas Development Institute (ODI), London.

National Agricultural Extension Research Liaison Services (NAERLS) (2017). N- Power Agro- Training Manual for Extension Advisors, 1 - 354. Editors; M. K, Othman, A. O, Lawal and A. O, Iyiola- Tunji. Federal Ministry of Agriculture and Rural Development, Abuja.

Odoemelam, L. E (2015): Interactions Between Indigenous Knowledge and Scientific Information: implication for effective integrated pest management practices In Contemporary issues in Agricultural Extension and Rural Development. Department of Agricultural Extension and Rural Development, Michael Okpara University of Agriculture, Umudike

Obinna, L.O, and Nzeakor, F. C. (2017). Adoption and utilization of modern rice processing technology packages among small- scale rice producers in Ebonyi State, Nigeria. J. of Agric. Economics, Extension and Sciences (JAEES) 3 (2) 100- 113 